\title{
HUBUNGAN STRATEGI DAN KINERJA DENGAN PENGGUNAAN SISTEM PENGENDALIAN MANAJEMEN SEBAGAI VARIABEL MODERATING
}

\author{
Tubagus Ismail dan Nurainun Bangun \\ Fakultas Ekonomi Universitas Sultan Ageng Tirtayasa dan Fakultas Ekonomi Universitas \\ Tarumanagara \\ Email:adeismai73@gmail.com daninun66@yahoo.com
}

\begin{abstract}
The relationship between management control systems (MSS) and the strategy does not only focus on the type of SPM is used, but on how managers in using SPM. This study investigated the effect of the use of diagnostic and interactive SPM on the relationship strategy and organizational performance. The nature of the relationship between SPM, strategies and performance depends on the organizational context. Research conducted on the SPM and strategies in developing countries is limited. The present study is the first empirical research conducted, which explores the relationship between the use of SPM, competitive strategy and organizational performance based on data obtained from the manufacturing companies in the province of Banten. The research findings support the view that both (the use of diagnostic and interactive) moderate the relationship between business strategy and performance. Respondents are 40 executive managers working in industry companies manufakutr in Banten Province. In this study, data analysis using Warp approach Partial Least Square (PLS) using PLS Warp Solfware 2:00 version. Another finding of this study is a moderate effect created by the use of diagnostic SPM is more significant when the cost leadership strategy that is applied to the performance. There is no evidence to support the proposition Porter exclusivity of the business strategy for better performance. Consequently, the results of this study have important implications for management practice and academic literature.
\end{abstract}

Keywords: Management Control Systems, strategy, performance.

\begin{abstract}
Abstrak: Hubungan antara sistem pengendalian manajemen (SPM) dan strategi tidak hanya fokus pada jenis SPM yang digunakan, melainkan pada cara manajer dalam menggunakan SPM. Penelitian ini menyelidiki pengaruh penggunaan diagnostik dan interaktif SPM pada hubungan strategi dan kinerja organisasi. Sifat dari hubungan antara SPM, strategi dan kinerja tergantung pada konteks organisasi. Penelitian yang dilakukan mengenai SPM dan strategi di negara-negara berkembang jumlahnya terbatas. Penelitian kali ini merupakan penelitian empiris pertama yang dilakukan, yang mengeksplorasi hubungan antara penggunaan SPM, strategi kompetitif dan kinerja organisasi berdasarkan data yang diperoleh dari perusahaan industri manufaktur di Provinsi Banten. Temuan penelitian mendukung pendapat bahwa keduanya (penggunaan diagnostik dan interaktif) memoderasi hubungan antara strategi bisnis dan kinerja. Responden penelitian ini adalah 40 eksekutif manajer yang bekerja di perusahaan industri manufakutr di Provinsi Banten. Dalam penelitian ini analisis data menggunakan pendekatan Warp Partial Least Square (PLS) dengan menggunakan Solfware Warp PLS versi 2.00. Temuan lain penelitian ini adalah efek moderat yang
\end{abstract}


Ismail dan Bangun: Hubungan Strategi dan KInerja Dengan Penggunaan Sistem...

diciptakan oleh penggunaan diagnostik SPM lebih signifikan ketika strategi kepemimpinan biaya yang diterapkan untuk kinerja. Tidak terdapat bukti yang mendukung eksklusifitas proposisi Porter dari strategi bisnis untuk kinerja yang lebih baik. Akibatnya, hasil penelitian ini mempunyai dampak penting bagi praktek manajemen dan literatur akademik.

Keywords: Sistem Pengendalian Manajemen, strategi, kinerja.

\section{PENDAHULUAN}

Dalam beberapa tahun terakhir, baik praktek akuntansi manajerial maupun riset telah menggunakan pendekatan yang lebih strategis dengan lebih fokus pada suatu hubungan antara sistem pengendalian manajemen (SPM) dan strategi untuk kinerja organisasi yang lebih baik dalam konteks organisasi yang berbeda (Ittner dan Larcker, 2001; Tucker et al., 2009 ). Kaplan dan Norton (2001) membuktikan bahwa dalam kerangka Balanced Scorecard (BSC) beberapa organisasi mencapai kinerja dengan menerapkan SPM yang disesusaikan dengan strategi organisasi. Langfield-Smith (1997) mengidentifikasi bahwa dalam konteks ini banyak penelitian empiris menggunakan pendekatan kontingensi dengan mencari hubungan sistematik antara unsur-unsur tertentu dari SPM dan strategi tertentu dari organisasi. Akan tetapi meningkatnya ketertarikan dalam meneliti hubungan antara SPM, strategi dan kinerja organisasi tidak didukung dengan kelengkapan penggambaran yang disajikan dalam literatur, Tucker et al (2009) menunjukkan bahwa pada pertengahan 2000-an sebagian besar hubungan strategi-kinerja SPM hanya sedikit yang didokumentasikan dan diteliti.

Fokus makalah ini yaitu pada cara manajer dalam menggunakan SPM bukan pada jenis SPM yang digunakan. Sesuai dengan literatur yang ada, terdapat dua jenis SPM yang biasa digunakan oleh manajemen yaitu penggunaan diagnostik dan penggunaan interaktif (Henri, 2006; Simons, 1995). Kedua jenis penggunaan ini akan menentukan cara seorang manajer dalam menggunakan sistem pengendalian mereka untuk memantau kinerja organisasi perusahaan. Chenhall (2003), Simons (1995), Abernethy dan Brownell (1999) menyimpulkan bahwa penelitian mengenai hubungan antara SPM dan strategi tidak hanya fokus pada jenis SPM yang digunakan, melainkan pada cara manajer dalam menggunakan SPM. Oleh karena itu, makalah ini mengkaji pengaruh penggunaan diagnostik dan interaktif SPM pada hubungan strategi dan kinerja organisasi.

Hal penting yang perlu diingat, bahwa sifat dari hubungan antara SPM, strategi dan kinerja tergantung pada konteks organisasi. Menurut Wickramasinghe dan Hopper (2005) penelitian yang dilakukan mengenai SPM dan strategi di negara-negara berkembang jumlahnya terbatas. Penelitian kali ini merupakan penelitian empiris pertama yang dilakukan, yang mengeksplorasi hubungan antara penggunaan SPM, strategi kompetitif dan kinerja organisasi berdasarkan data yang diperoleh dari perusahaan industri manufaktur di Provinsi Banten.

Penelitian ini bertujuan untuk menguji masalah "bagaimana penggunaan SPM (diagnostik dan interaktif) dapat mempengaruhi hubungan strategi bisnis dan kinerja organisasi". Dalam rangka memperluas pemahaman mengenai hubungan SPM strategikinerja, penelitian ini diharapkan dapat mencapai tiga tujuan sebagai berikut: (1) Mengidentifikasi pengaruh dari moderasi yang diciptakan oleh setiap penggunaan SPM (penggunaan diagnostik dan interaktif) terhadap hubungan antara strategi bisnis dan 
kinerja organisasi, (2) Menyelidiki pengaruh dari strategi bisnis pada kinerja organisasi, dan (3) Menyelidiki keterkaitan antara strategi kepemimpinan biaya dan strategi diferensiasi.

Kerangka strategi generic Porter $(1980,1985)$ Secara luas digunakan sebagai dasar untuk berbagai penelitian lanjutan dalam penelitian digunakan sebagai kunci dari setiap tipologi strategi. Menurut Porter $(1980,1985)$ untuk mencapai keunggulan kompetitif jangka panjang dan kinerja di atas rata-rata, suatu organisasi harus mengadopsi salah satu antara strategi kepemimpinan biaya dan strategi diferensiasi. Namun, pendapat porter tersebut dikritik oleh sejumlah peneliti (Hill, 1988; Murray, 1988; Sands, 2006) yang menolak eksklusivitas temuan empiris dari dua strategi generic. Penelitian ini juga ini betujuan untuk mengevaluasi keakurasian sumber proposisi tunggal Porter untuk mencapai keunggulan kompetitif jangka panjang dan kinerja yang unggul.

\section{KAJIAN TEORI}

Sistem Pengendalian Manajemen. Anthony (1965) mendefinisikan SPM sebagai proses dimana seorang manajer menjamin bahwa sumber daya diperoleh dan digunakan secara efektif dan efisien dalam mencapai tujuan organisasi; sedangkan Simons (1995) mendefinisikan SPM sebagai sarana dasar untuk mencapai keberhasilan dalam menerapkan strategi dan SPM didefinisikan sebagai informasi formal berbasis rutinitas serta prosedur manajer yang digunakan untuk mempertahankan atau mengubah pola dalam kegiatan organisasi. Simons (1995) berpendapat bahwa fakta yang paling penting bukanlah identifikasi jenis pengendalian perusahaan, melainkan bagaimana pengendalian perusahaan tersebut digunakan, yang akan menghasilkan perbedaan dalam kerangka kerja 'levers of control' antara penggunaan pengendalian diagnostik dan interaktif. Seperti yang dikemukakan oleh Thoren dan Brown (2004), perbedaan antara sistem pengendalian diagnostik dan interaktif tidak terletak pada ciri rancangan teknis, tetapi pada cara manajer dalam menggunakan sistem tersebut. Tabel 1 memberikan perbandingan penggunaan diagnostik dan penggunaan interaktif dari SPM berdasarkan kriteria tertentu.

Strategi Bisnis. Teori Porter mengenai bisnis stragtegi generik (kompetitif) merupakan salah satu kontribusi paling besar dan berpengaruh dalam mempelajari strategi bisnis organisasi. Menurut Porter (1980, 1985), perusahaan yang mencoba menjadi produsen dengan menetapkan biaya terendah dalam suatu industri dapat disebut sebagai pengguna strategi "kepemimpinan biaya", Sedangkan perusahaan yang mengadopsi "strategi diferensiasi" akan mampu membedakan produk atau jasa mereka dan menetapkan harga premium di pasar (Hanson et al., 2008). Menurut Porter, banyak perusahaan menggunakan dua strategi ini baik di pasar massal atau dalam ceruk pasar tertentu. Namun, Porter juga menekankan bahwa kedua strategi ini harus saling eksklusif. Porter (1980, 1985) memperkirakan bahwa untuk mencapai hasil kinerja keuangan jangka panjang di atas ratarata, perusahaan harus menerapkan baik strategi kepemimpinan biaya ataupun strategi diferensiasi, dan bagi perusahaan yang tidak menerapkan salah satu dari kedua strategi ini perusahaan akan 'stuck in the middle' dan keahlian dalam kinerja keuangan jangka panjang menjadi di bawah rata-rata.

Kinerja Organisasi. Kinerja organisasi adalah salah satu konstruksi paling penting dalam penelitian akuntansi dan manajemen. Menurut Richard et al (2009), kinerja organisasi adalah kriteria yang paling penting dalam mengevaluasi organisasi, setiap tindakan, dan 
lingkungan. Ruang lingkup terkecil dari kinerja organisasi dalam perusahaan meliputi tiga bidang tertentu: (1) kinerja keuangan (misalnya laba, return on asset, return on investment), (2) kinerja pasar (misalnya: penjualan, pangsa pasar), dan (3) pemegang saham (misalnya total return pemegang saham, nilai tambah ekonomi).

Indeks kinerja organisasi tercermin dalam kerangka kerja Balanced Scorecard (BSC) (Kaplan dan Norton, 1992) yang digunakan sebagai kerangka pengukuran kinerja yang menggabungkan langkah-langkah strategis kinerja non-keuangan untuk melengkapi metrik keuangan tradisional, untuk memberikan pemahaman yang sama mengenai kinerja organisasi kepada manajer dan eksekutif (Norreklit, 2000). Berdasarkan penelitian sebelumnya, untuk menggabungkan multi-dimensi dalam mengukur kinerja organisasi tidak dapat hanya mengandalkan ukuran keuangan tradisional (Kaplan dan Norton, 2001; Norreklit, 2000).

Pengembangan Hipotesis. Pemahaman mengenai sumber kinerja organisasi menjadi fokus utama dalam penelitian akuntansi dan manajemen (Richard et al., 2009). perkembangan bukti-bukti pada studi empiris menunjukkan bahwa keberhasilan dalam perumusan dan pelaksanaan strategi di tingkat bisnis (kompetitif) memiliki dampak positif pada kinerja organisasi (misalnya Dess dan Davis, 1984; Hambrick, 1983; Hill, 1988; Rubach dan McGee, 2004; Sands, 2006). Menariknya, Para peneliti di bidang akuntansi manajemen menyadari bahwa memperluas riset atas hubungan antara strategi dan kinerja dengan menggunakan SPM sebagai variabel moderating merupakan suatu kebutuhan (misalnya Simons, 1990; Govindarajan dan Gupta,1985). Meskipun literatur yang ada menunjukkan bahwa diagnostik atau interaktif SPM dapat digunakan untuk menghasilkan strategi dan kinerja organisasi yang lebih baik (Henri, 2006; Simons, 1995; Abernethy dan Brownell, 1999), namun sejauh mana dua penggunaan SPM tersebut memberikan dampak terhadap strategi kinerja yang saling berhubungan sebagian besar masih belum diteliti.

Sebagaimana ditekankan oleh Porter $(1980,1985)$ organisasi dapat memperoleh keunggulan kompetitif dalam pasar yang luas ataupun sempit dengan mengadopsi baik strategi "kepemimpinan biaya" atau dengan strategi "diferensiasi". Porter (1985) menentukan bahwa strategi kepemimpinan biaya berpotensi dalam menetapkan laba ratarata di industri yang dilakukan dengan dua cara: (i) menghasilkan produk organisasi dengan biaya lebih rendah dari pesaing dan dengan penetapan harga pasar yang sama (yang mengarah ke keuntungan yang lebih tinggi dari margin per unit) dan (ii) menghasilkan produk dengan biaya lebih rendah dari pesaing dan dengan menetapkan harga yang lebih rendah dari pelanggan (yang mengarah kepada pangsa pasar yang lebih tinggi). Oleh karena itu, strategi kepemimpinan biaya menimbulkan keuntungan yang tinggi (Rubach dan McGee, 2004). Sebaliknya, strategi diferensiasi dapat menimbulkan biaya yang lebih tinggi, tetapi akan memungkinkan perusahaan untuk memperoleh penghasilan lebih tinggi pula dengan menawarkan produk berkualitas lebih tinggi dari pesaing (Wright, 1987).

Menurut Wright (1987) strategi diferensiasi relatif dapat menciptakan keunggulan kompetitif jika jangka waktunya panjang karena penggunaan strategi diferensasi menimbulkan suatu kesulitan pada saat peniruan dan mobilitas yang tidak sempurna pada sumber daya organisasi. Selain itu, Hanson et al (2008) memberikan faktor lain dalam mempertahankan diferensiasi berbasis keunggulan kompetitif yaitu dengan "reinvesting margins". Literatur yang ada mendukung pandangan bahwa organisasi dapat menetapkan harga premium dengan menawarkan produk yang unik dan memungkinkan organisasi 
untuk mendapatkan pendapatan serta keuntungan yang lebih banyak (Porter, 1985; Wright, 1987). Oleh karena itu, hipotesis yang diajukan sebagai berikut:

H1: strategi kepemimpinan biaya berpengaruh positif terhadap kinerja organisasi.

$\mathrm{H} 2$ : Strategi diferensiasi berpengaruh positif terhadap kinerja organisasi.

Untuk menjamin kinerja yang lebih baik strategi kompetitif generik harus menggambarkan suatu alternatif yang saling eksklusif (Porter, 1980; 1985). Menurut Porter (1985) penggunaan kepemimpinan biaya dan diferensiasi secara bersama-sama cenderung mahal dan dengan memfokuskan seluruh kegiatan untuk semua orang, perusahaan akan mengelola organisasi dengan biasa-biasa saja. Tipologi strategi Porter selain menerima dukungan yang cukup, tetapi juga menerima penolakan pada front empiris (Hill, 1988; Murray, 1988; Wright, 1987; Miller; 1992). Namun, menurut Rubach dan McGee (2004) sebagian besar penelitian sebelumnya mendukung eksklusifitas proposisi Porter pada perusahaan manufaktur. Adalah tidak bijaksana untuk menolak argumen Porter mengenai eksklusivitas dari segi strategi generik, terutama karena tidak ada studi empiris yang telah dilakukan sejauh ini mengenai industri manufaktur di Provinsi Banten yang memeriksa eksklusivitas strategi kompetitif secara realitas. Oleh karena itu, hipotesis yang diajukan sebagai berikut :

H3: terdapat hubungan negatif antara strategi kepemimpinan biaya dan strategi diferensiasi.

Penelitian ini bertujuan untuk mengeksplorasi dampak yang terjadi akibat dua penggunaan SPM yaitu diagnostik dan interaktif, sehingga dikembangkan Hipotesis 4 sampai 7. Menurut Henri (2006), penggunaan diagnostik mencerminkan dua ciri penting yang terkait dengan pengendalian mekanistik: (i) pengendalian yang ketat dari operasi dan strategi, dan (ii) saluran komunikasi sangat terstruktur dan arus informasi dibatasi (Burns dan Stalker, 1961). persyaratan dari strategi kepemimpinan biaya adalah dengan berasumsi bahwa dengan menetapkan pengendalian yang ketat dapat menguntungkan bagi pengurangan biaya dalam rangka meningkatkan kinerja organisasi (Sands, 2006). Namun, tidak ada penelitian yang dilakukan untuk mengetahui bahwa efek yang diciptakan oleh penggunaan diagnostik lebih dari asosiasi antara strategi kepemimpinan biaya dan kinerja.

Umumnya, penggunaan diagnostik dipaparkan oleh para peneliti sebagai suatu penentu yang dapat menimbulkan hubungan negatif dan mengahambat inovasi dalam menentukan diferensiasi serta dapat menciptakan kendala dalam memastikan kepatuhan terhadap suatu perintah (Henri,2006; Simons, 1995). Hal yang sama dikemukakan Otley (1994) mengidentifikasi bahwa penggunaan diagnostik tradisional dari SPM akan mendorong konservatisme dan hasilnya dapat menurunkan kreativitas serta mengurangi keunikan dari suatu produk. Berdasarkan hal tersebut Otley dan Simons memfokuskan pada kemungkinan adanya hubungan negatif antara penggunaan diagnostik SPM dan strategi diferensiasi. Namun, tidak ada bukti empiris yang mendukung yang disediakan oleh Otley maupun Simons dalam menciptakan suatu hubungan negatif antara penggunaan diagnostik dan strategi diferensiasi.

Sebaliknya, penggunaan interaktif mencerminkan dua ciri penting yang terkait dengan keseimbangan dalam pengendalian: (i) pengendalian tidak ketat dan informal yang mencerminkan norma-norma kerjasama, adanya komunikasi dan penekanan pada penyelesaian sesuatu, dan (ii) membuka saluran komunikasi dan arus informasi di seluruh organisasi (burns dan Stalker, 1961; Henri, 2006). Menurut Simons (1995, hal 95) penggunaan interaktif memiliki pengaruh dalam menciptakan hubungan positif yang mendorong terjadinya peningkatan kreatifitas dan inspirasi. Manajer senior menggunakan 
sistem pengendalian interaktif untuk membangun tekanan internal untuk keluar dari rutinitas pencarian dalam ruang lingkup sederhana, merangsang pencarian peluang dan mendorong munculnya inisiatif dari strategi-strategi baru (Simons, 1995). Menurut Dent (1987), rasa ingin tahu dan eksperimen (rasa ingin mencoba) dapat dikembangkan dengan penggunaan interaktif dari SPM dan hasilnya dapat menyebabkan strategi di tingkat bisnis menjadi lebih baik dengan mengurangi biaya dan/atau produk yang unik untuk meningkatkan kinerja perusahaan. Namun, dengan tidak adanya bukti empiris yang mendalam, dampak yang ditimbulkan oleh penggunaan interaktif dari SPM atas kepemimpinan biaya dan strategi diferensiasi yang mengarah ke kinerja organisasi perlu dieksplorasi.

Menariknya, disamping menjelaskan pembagian antara penggunaan diagnostik dan interaktif dari SPM, literatur yang ada juga mendukung penggunaan SPM dengan menerapkan konsep dynamic tension. Seperti yang disarankan oleh conflict literature, penekanan tidak selalu menghasilkan kerugian tetapi mungkin bermanfaat bagi organisasi (DeDreu, 1991; Nicotera, 1995). Seperti dalam penelitiannya, Henri (2006) menyimpulkan bahwa penggunaan SPM dapat memperkuat hubungan strategi kinerja. Namun, karena bukti empiris yang tersedia tidak memadai atau ambigu, hubungan yang tepat sulit untuk ditentukan. Jadi, hipotesis yang diajukan yaitu :

H4: Penggunaan diagnostik SPM memoderasi hubungan strategi kepemimpinan biaya dan kinerja organisasi.

H5: Penggunaan interaktif SPM memoderasi hubungan strategi kepemimpinan biaya dan kinerja organisasi.

H6: Penggunaan diagnostik SPM memoderasi hubungan strategi diferensiasi dan kinerja organisasi.

H7: Penggunaan interaktif SPM memoderasi hubungan strategi diferensiasi dan skinerja organisasi.

\section{METODE}

Penelitian ini menggunakan metode survei, data yang digunakan dalam penelitian diperoleh dengan pendistribusian kuesioner yang diberikan kepada responden secara langsung dengan terlebih dahulu melakukan wawancara. Sampel penelitian ini merupakan perusahaan-perusahaan industry manufaktur di Provinsi Banten. Sampel dalam penelitian ini adalah 40 manajer yang bekerja di perusahaan industri manufaktur di Provinsi Banten. Sedangkan yang menjadi responden dalam sampel penelitian ini adalah manajer tingkat eksekutif. Adapun kriteria dari responden adalah manajer yang telah bekerja minimal 2 tahun dalam perusahaan tersebut. Pengambilan data melalui mail survey dan diantar langsung kepada responden, sedangkan instrument yang digunakan adalah kuesioner.

Konsep-konsep penting yang berkaitan dengan penelitian ini yaitu: (i) strategi tingkat bisnis (ii) penggunaan SPM dan (iii) kinerja organisasi. Semua indikator pengembangan dioperasionalkan dan dikukur dengan skala likert 1-5,. Dua strategi tingkat bisnis utama, yaitu: kepemimpinan biaya dan diferensiasi, yang dioperasionalkan dengan menggunakan item pengukuran yang dihasilkan dari penelitian strategi manajemen sebelumnya.

Strategi kepemimpinan biaya yaitu perusahaan yang mencoba menjadi produsen dengan menetapkan biaya terendah dalam suatu industri (Porter, 1980, 1985). Pengukuran strategi kepemimpinan biaya mengacu pada instrument yang didasarkan pada penelitian 
sands (2006) yaitu (1) biaya terendah peruint dari pesaing, (2) harga produk dibawah pesaing, (3) pengendalian biaya sangat ketat, (4) memproduksi produk standar, (5) fungsi outsource untuk mengendalikan biaya, (6) teknologi untuk menurunkan biaya, (7) analisis biaya terkait dengan kegiatan, (8) hadiah untuk karyawan untuk saran pengurangan biaya.

Strategi diferensiasi bertujuan untuk membedakan produk atau jasa dan menetapkan harga premium di pasar (Hanson et al., 2008). Pengukuran strategi diferensiasi mengacu pada instrument yang didasarkan pada penelitian sands (2006) yaitu (1) atribut produk yang berbeda, (2) identifikasi merek merupakan prioritas, (3) fitur unik ditekankan dalam promosi, (4) membina inovasi adalah priotitas, (5) teknologi digunakan untuk membedakan produk, (6) hadiah untuk karyawan apabila mengusulkan produk yang unik.

Penggunaan diagnostik dan interaktif SPM mengacu pada instrumen yang didasarkan pada penelitian yang dikembangkan oleh Vandenbosch (1999). Pengukuran diagnostic terdiri dari: (1) target kinerja ditetapkan diawal, (2) target kinerja ditetapkan tanpa mempertimbangakan sudut pandang bawahan (3) SPM mengevaluasi dan mengendalikan bawahan dengan ketat, (4) SPM digunakan untuk menyelaraskan ukuran kinerja dengan tujuan strategis, (5) SPM digunakan untuk menindaklanjuti rencana dan tujuan yang dilaksanakan, (6) SPM dianggap sebagai alat yang tersedia untuk dipelajari, (7) SPM digunakan untuk menindaklanjuti pengecualian yang signifikan dan penyimpangan (8) hadiah untuk karyawan ditentukan dengan formula berdasarkan pencapaian target.

Pengukuran interaktif terdiri dari: (1) SPM sering digunakan sebagai sarana untuk mempertanyakan dan berdebat asumsi yang sedang berlangsung, keputusan dan rencana nyata, (2) SPM digunakan untuk menantang ide-ide dan cara melakukan tugas, (3) SPM dibahas secara teratur dan sering dalam setiap pertemuan antara atasan dan bawaha, (4) permintaan SPM sering dan teratur terhadap manajer operasi dan bawahan di semua tingkat organisasi, (5) SPM menghasilkan informasi yang membentuk agenda penting dan berulang dalam diskusi antara manajer operasional dan senior, (6) hadiah bagi karyawan ditentukan oleh konstribusi karyawan terhadap inovasi.

Kinerja Organisasi diakui sebagai konsep multidimensi. Sebagai konsekuensinya, pengukuran 18 item digunakan untuk menetapkan sifat multidimensi pada konsep kinerja organisasi. Item-item ini mengacu pada instrumen yang didasarkan pada penelitian Govindarajan dan Fisher, 1990; Hoque dan James, 2000 yaitu (1) pangsa pasar, (2) pertumbuhan penjualan, (3) net profit margin,(4) biaya per unit, (5) return on investmen, (6) jumlah barang reject, (7) waktu pemrosesan produk, (8) jumlah keluhan pelanggan, (9) tingkat putus sekolah pelanggan, (10) omset karyawan, (11) ketidakhadiran karyawan, (12) produk baru diperkenalkan ke pasar, (13) teknik produksi baru dan proses yang digunakan, (14) beban pokok penjualan, (15) kinerja pengiriman ke pelanggan berdasar tanggal, (16) kinerja pengiriman ke pelanggan berdasar, (17) penjualan kembali, (18) persentase penjualan dari produk baru.

Metode Analisis Data. Dalam penelitian ini analisis data menggunakan pendekatan Partial Least Square (PLS) dengan menggunakan Solfware Warp PLS versi 2.00. PLS adalah model persamaan struktural (SEM) yang berbasis komponen atau varian (variance). Menurut Ghozali (2006) PLS lebih bersifat predictive model. PLS merupakan metode analisis yang tidak didasarkan pada banyak asumsi. Misalnya, sampel tidak harus besar. Selain dapat digunakan untuk menjelaskan ada tidaknya hubungan antar variabel laten. 


\section{HASIL DAN PEMBAHASAN}

Tingkat Respond dan Statistik Deskriptif. Kuesioner yang disebarkan sejumlah 95 kuesioner. Dari jumlah kuesioner yang dibagikan, kuesioner yang diisi dan dikembalikan adalah sejumlah 40 kuesioner dengan tingkat respon rate sebesar $42,10 \%$. Kuesioner yang tidak kembali disebabkan responden tengah dalam kesibukan sehingga tidak sempat untuk menjawab kuesioner. Oleh karena itu, jumlah data yang dapat diolah untuk analisis adalah sejumlah 40 kuesioner.

Tabel 1. Tingkat Respon

\begin{tabular}{clc}
\hline No & \multicolumn{1}{c}{ KETERANGAN } & JUMLAH \\
\hline 1 & Kuesioner yang disebar & 95 \\
2 & Kuesioner yang tidak kembali & 55 \\
3 & Kuesioner yang tidak lengkap & 0 \\
4 & Kuesioner yang kembali & 40 \\
5 & Kuesioner yang bisa diolah & 40 \\
6 & Tingkat respon (40/95)*100\% & $42,10 \%$ \\
\hline
\end{tabular}

Analisis statistik deskriptif diperoleh dengan menggunakan software SPSS. Hasil statistik descriptif ditunjukkan pada Tabel 2, berdasarkan tabel tersebut kinerja organisasi sebagai variabel dependen memiliki rata-rata yang cukup tinggi. Untuk staregi kepemimpinan biaya dan strategi diferensiasi sebagai variabel independen memiliki ratarata yang cukup tinggi. Serta diagnostik dan interaktif yang digunakan untuk memoderasi strategi kepemimpinan biaya dan strategi diferensiasi dengan kinerja organisasi memiliki rata-rata yang cukup tinggi.

Tabel 2. Descriptif Statistik

\begin{tabular}{|c|c|c|c|c|c|c|}
\hline & $\mathrm{N}$ & Minimum & Maximum & Mean & $\begin{array}{c}\text { Std. } \\
\text { Deviation }\end{array}$ & Variance \\
\hline $\begin{array}{l}\text { Kinerja } \\
\text { Organisasi }\end{array}$ & 40 & 1 & 5 & 3,50 & ,934 & ,872 \\
\hline $\begin{array}{l}\text { Strategi } \\
\text { Kepemimpinan } \\
\text { Biaya }\end{array}$ & 40 & 1 & 5 & 3,13 & 1,181 & 1,394 \\
\hline $\begin{array}{l}\text { Strategi } \\
\text { Diferensiasi }\end{array}$ & 40 & 1 & 5 & 3,80 & 1,018 & 1,036 \\
\hline Diagnostik & 40 & 2 & 5 & 3,15 & ,921 & 849 \\
\hline $\begin{array}{l}\text { Interaktif } \\
\text { Valid N } \\
\text { (listwise) }\end{array}$ & $\begin{array}{l}40 \\
40\end{array}$ & 1 & 5 & 3,10 & 1,172 & 1,374 \\
\hline
\end{tabular}

Uji Validitas. Pengujian validitas data dalam penelitian ini adalah dengan menggunakan software PLS version 2.0 dengan Outer Model yaitu Convergent Validity yang dilihat dengan nilai square root of average variance extracted (AVE) masing-masing konstruk, dimana nilainya harus lebih besar dari 0,5. Tabel 4 menjelaskan nilai AVE, dapat dilihat bahwa setiap konstruk (variabel) tersebut memiliki nilai AVE diatas 0,5. Hal ini menunjukkan bahwa setiap konstruk tersebut memiliki nilai validitas yang baik dari setiap indikatornya atau kuesioner yang digunakan valid. 
Ismail dan Bangun: Hubungan Strategi dan KInerja Dengan Penggunaan Sistem...

Tabel 3. AVE, R Square, Composite Reliability, Cronbachs Alpha

\begin{tabular}{lcccc}
\hline \multicolumn{1}{c}{ Keterangan } & AVE & R Square & $\begin{array}{c}\text { Composite } \\
\text { Reliability }\end{array}$ & $\begin{array}{c}\text { Cronbachs } \\
\text { Alpha }\end{array}$ \\
\hline Diagnostik & 0,828623 & & 0,906236 & 0,795638 \\
Interaktif & 0,850172 & & 0,919019 & 0,823768 \\
Kinerja Organisasi & 0,682070 & 0,810128 & 0,914555 & 0,884707 \\
Strategi & 0,910337 & 0,757599 & 0,953064 & 0,901599 \\
Diferensiasi & & & & \\
SD*Diagnostik & 0,718217 & & 0,910505 & 0,870404 \\
SD*Interaktif & 0,644394 & & 0,876692 & 0,819207 \\
Strategi & 0,748352 & & 0,855694 & 0,771898 \\
Kepemimpinan & & & \\
Biaya & & & \\
SKP*Diagnostik & 0,697637 & & 0,902182 & 0,856655 \\
SKP*Interaktif & 0,519622 & & 0,793836 & 0,718892 \\
\hline
\end{tabular}

Uji Reliabilitas. Pengujian reliabilitas dilakukan dengan menganalisis composite reliability dan cronbach's alpha.Sesuai dengan aturan yang lazim dipakai bahwa composite reliability dan cronbach's alpha lebih dari 0.7 menunjukkan tingkat reliabilitas yang cukup baik (Hulland, 1999). Dari tabel 4 dapat dilihat setiap konstruk atau variabel laten tersebut memiliki nilai composite reliability dan cronbach's alpha diatas 0,7 yang menandakan bahwa internal consistency dari antar variabel memiliki reliabilitas yang baik.

Full Model Structural. Dalam gambar 1 dapat dilihat bahwa setiap konstruk dari masing masing variabel dijelaskan oleh masing-masing indikator. Dimana model pada gambar 1 dilakukan eliminasi, hal ini disebabkan terdapat korelasi konstruk yang kurang dari 0,5 sehingga setiap variable baru memenuhi kriteria convergentvalidity setelah dilakukan eliminasi.

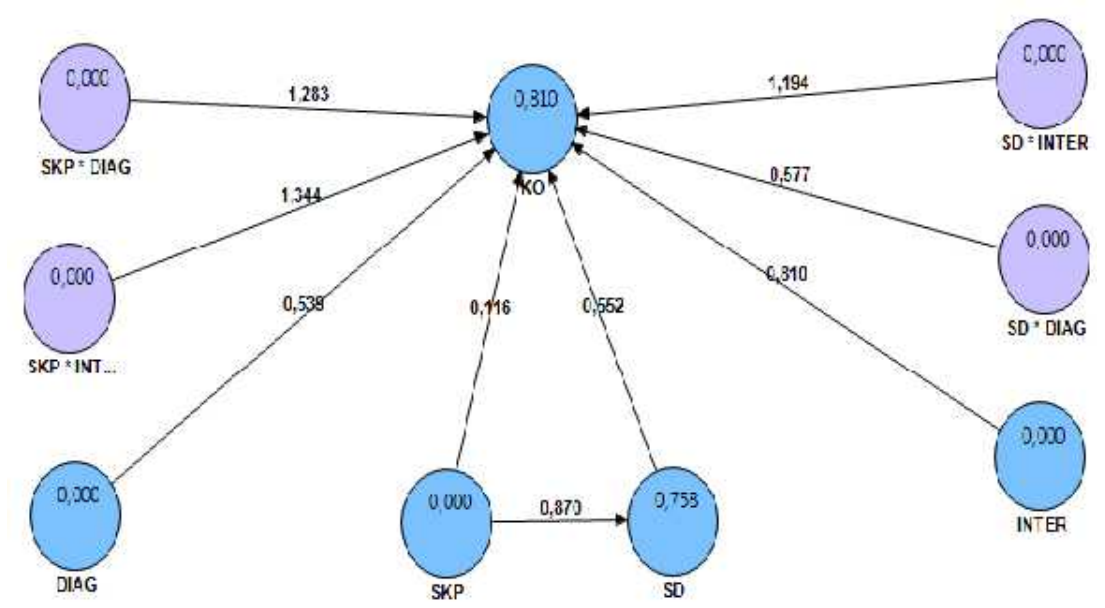

Gambar 1. Output Pengujian dengan Warp PLS 2.0 
Untuk menguji hipotesis yang diajukan, dapat dilihat besarnya nilai t-statistik. Batas untuk menolak dan menerima hipotesis yang diajukan adalah $\pm 1,96$, dimana apabila nilai $t$ berada pada rentang nilai -1,96 dan 1,96 maka hipotesis akan ditolak atau dengan kata lain menerima hipotesis nol (H0). Hasil estimasi t-statistik dapat dilihat pada result for inner weight Tabel 4.

Tabel 4. Result For Inner Weight

\begin{tabular}{|c|c|c|c|c|c|}
\hline & $\begin{array}{c}\text { Original } \\
\text { Sample (O) }\end{array}$ & $\begin{array}{c}\text { Sample } \\
\text { Mean (M) }\end{array}$ & $\begin{array}{l}\text { Standard } \\
\text { Deviation } \\
\text { (STDEV) }\end{array}$ & $\begin{array}{l}\text { Standard Error } \\
\text { (STERR) }\end{array}$ & $\begin{array}{l}\text { T Statistics } \\
\text { (|O/STERR } \mid)\end{array}$ \\
\hline DIAG $->$ KO & 0,539172 & 0,495913 & 0,118357 & 0,118357 & 4,555490 \\
\hline INTER -> KO & 0,809983 & 0,767649 & 0,134501 & 0,134501 & 6,022157 \\
\hline $\mathrm{SD} \rightarrow \mathrm{KO}$ & 0,552408 & 0,565628 & 0,141128 & 0,141128 & 3,914220 \\
\hline $\begin{array}{c}\text { SD } * \text { DIAG -> } \\
\text { KO }\end{array}$ & 0,577473 & 0,457229 & 0,268037 & 0,268037 & 2,154450 \\
\hline $\begin{array}{c}\text { SD } * \text { INTER - } \\
>\text { KO }\end{array}$ & 1,194004 & 1,045877 & 0,302627 & 0,302627 & 3,945462 \\
\hline SKP -> KO & 0,365264 & 0,339302 & 0,058396 & 0,058396 & 6,254959 \\
\hline SKP -> SD & 0,870402 & 0,874930 & 0,015080 & 0,015080 & 57,718371 \\
\hline $\begin{array}{c}\mathrm{SKP} * \mathrm{DIAG}- \\
>\mathrm{KO}\end{array}$ & 1,283070 & 1,128257 & 0,390154 & 0,390154 & 3,288626 \\
\hline $\begin{array}{c}\text { SKP } * \text { INTER } \\
->\text { KO }\end{array}$ & 1,344171 & 1,158506 & 0,392689 & 0,392689 & 3,42299 \\
\hline
\end{tabular}

Untuk menguji hipotesis yang diajukan, dapat dilihat besarnya nilai tstatistik. Batas untuk menolak dan menerima hipotesis yang diajukan adalah $\pm 1,96$, dimana apabila nilai $\mathrm{t}$ berada pada rentang nilai -1,96 dan 1,96 maka hipotesis akan ditolak atau dengan kata lain menerima hipotesis nol (H0). Hasil estimasi t-statistik dapat dilihat pada tabel 6.

Hipotesis 1 menyatakan bahwa strategi kepemimpinan biaya memiliki hubungan yang positif dan signifikan terhadap kinerja organisasi yang ditunjukan dengan nilai original sampel estimate sebesar 0,365264 dan T-statistik sebesar 6,254959 lebih besar dari t-hitung yaitu 1.96 dengan demikian Hipotesis 1 diterima. Berdasarkan hasil tersebut, temuan ini konsisten dengan penelitian Porter (1985). Dengan mengadopsi strategi kepemimpinan biaya, organisasi dapat memperoleh keunggulan kompetitif yaitu dengan menghasilkan produk dengan biaya lebih rendah dari pesaing yang akan menghasilkan keuntungan yang tinggi.

Hipotesis 2 menyatakan bahwa strategi diferensiasi memiliki hubungan yang positif dan signifikan terhadap kinerja organisasi yang ditunjukan dengan nilai original sampel estimate sebesar 0,552408 dan T-statistik sebesar 3,914220 yang lebih besar dari t-hitung yaitu 1.96 dengan demikian Hipotesis 2 diterima. Berdasarkan hasil tersebut, temuan ini konsisten dengan penelitian Porter (1985); Wright, (1987). Dengan mengadopsi strategi diferensiasi, organisasi dapat memperoleh keunggulan kompetitif yaitu dengan menghasilkan produk dengan kualitas lebih tinggi dari pesaing karna menghasilkan produk yang unik. 
Hipotesis 3 menyatakan strategi kepemimpinan biaya memiliki hubungan yang negatif dan tidak signifikan terhadap strategi diferensiasi. Namun, hasil menunjukkan nilai original sampel estimate sebesar 0,870402 dan T-statistik sebesar 57,718371 yang lebih besar dari t-hitung yaitu 1.96 dengan demikian Hipotesis 3 ditolak. Berdasarkan hasil tersebut, temuan ini menolak penelitian porter (1980,1985). penggunaan strategi kepemimpinan biaya dan diferensiasi secara bersama-sama cenderung mahal, dengan hasil tersebut penelitian ini mendukung pandangan Hill (1988) yang berpendapat bahwa model Porter cacat fundamental dalam hal ini, karna penggunaan strategi kepemimpinan biaya dan strategi diferensiasi mungkin ada dan sesuai seperti dalam penelitian ini.

Hipotesis 4 menyatakan penggunaan diagnostik SPM memoderasi hubungan strategi kepemimpinan biaya dan kinerja organisasi menunjukkan hubungan positif yang ditunjukan dengan nilai original sampel estimate sebesar 1,283070 dan T-statistik sebesar 3,288626 yang lebih besar dari t-hitung yaitu 1.96 dengan demikian Hipotesis 4 diterima. Berdasarkan hasil tersebut, temuan ini konsisten dengan penelitian Henri (2006). Menurut Henri diagnostik SPM signifikan memoderasi hubungan antara strategi bisnis dan kinerja organisasi.

Hipotesis 5 menyatakan penggunaan interaktif SPM memoderasi hubungan strategi kepemimpinan biaya dan kinerja organisasi menunjukkan hubungan positif yang ditunjukan dengan nilai original sampel estimate sebesar 1,344171 dan T-statistik sebesar 3,42299 yang lebih besar dari t-hitung yaitu 1.96 dengan demikian Hipotesis 5 diterima. Berdasarkan hasil tersebut, temuan ini konsisten dengan penelitian Henri (2006). Menurut Henri interaktif SPM signifikan memoderasi hubungan antara strategi bisnis dengan kinerja organisasi.

Hipotesis 6 menyatakan penggunaan diagnostik SPM memoderasi hubungan strategi diferensiasi dan kinerja organisasi menunjukkan hubungan positif yang ditunjukan dengan nilai original sampel estimate sebesar 0,577473 dan T-statistik sebesar 2,154450 yang lebih besar dari t-hitung yaitu 1.96 dengan demikian Hipotesis 6 diterima. Berdasarkan hasil tersebut, temuan ini konsisten dengan penelitian Henri (2006). Menurut Henri diagnostik SPM signifikan memoderasi hubungan antara strategi bisnis dan kinerja organisasi.

Hipotesis 7 menyatakan penggunaan interaktif SPM memoderasi hubungan strategi diferensiasi dan kinerja organisasi menunjukkan hubungan positif yang ditunjukan dengan nilai original sampel estimate sebesar 1,194004 dan T-statistik sebesar 3,945462 yang lebih besar dari t-hitung yaitu 1.96 dengan demikian Hipotesis 7 diterima. Berdasarkan hasil tersebut, temuan ini konsisten dengan penelitian Henri (2006). Menurut Henri interaktif SPM signifikan memoderasi hubungan antara strategi bisnis dengan kinerja organisasi.

Tabel 5. Hasil Pengujian Hipotesis

\begin{tabular}{lc}
\hline \multicolumn{1}{c}{ Hipotesis } & pendukung \\
\hline H1: strategi kepemimpinan biaya secara positif mempengaruhi kinerja & diterima \\
$\quad$ organisasi. & \\
H2: Strategi Diferensiasi secara positif mempengaruhi kinerja organisasi. & diterima \\
H3: strategi kepemimpinan biaya secara negatif mempengaruhi strategi & ditolak \\
$\quad$ diferensiasi. & diterima \\
H4: penggunaan Diagnostik dari SPM menghubungkan strategi & \\
$\quad$ kepemimpinan biaya dengan kinerja organisasi. & diterima \\
H5: penggunaan Interaktif dari SPM menghubungkan strategi kepemimpinan
\end{tabular}


biaya dengan kinerja organisasi.

H6: penggunaan Diagnostik dari SPM menghubungkan strategi diferensiasi diterima dengan kinerja organisasi.

H7: penggunaan Interaktif SPM menghubungkan strategi diferensiasi dengan diterima kinerja organisasi.

\section{PENUTUP}

Simpulan. Hasil penelitian memiliki implikasi teoritis dan praktis yang signifikan. Perkembangan terkini dalam literatur akuntansi manajemen menampilkan klaim yang kuat tentang pentingnya substantif mengembangkan hubungan yang tepat antara penggunaan SPM, variabel strategi dan kinerja organisasi (Kaplan dan Norton, 2001; Langfield-Smith, 1997; Simons, 1995; 2000; Tucker et al., 2009). Sebagai akhir penelitian, penggunaan diagnostik dan interaktif secara bersamaan dalam menguji efek moderasi sudah tidak dianggap, temuan penelitian ini adalah penting. Penelitian kali ini telah menunjukkannya melalui pengujian Hipotesis H4 sampai H7, bahwa dua penggunaan SPM secara signifikan dapat memoderasi hubungan antara strategi bisnis dan kinerja organisasi. Hal ini memungkinkan untuk disimpulkan bahwa penggunaan diagnostik menciptakan dampak yang lebih signifikan atas strategi kepemimpinan biaya sedangkan penggunaan interaktif menciptakan efek yang lebih signifikan untuk strategi diferensiasi. Sehingga, penelitian ini menyimpulkan bahwa penggunaan SPM secara bersamaan tidak tepat meskipun situasi tersebut dapat menciptakan penekanan yang sesuai dengan konflik literatur (DeDreu, 1991; Nicotera, 1995).

Penelitian ini juga menentang teori Porter $(1980,1985)$ mengenai strategi kompetitif generic. Menurut Porter (1985) penggunaan kepemimpinan biaya dan diferensiasi secara bersama-sama cenderung mahal, dengan demikian model Porter tersebut ditandai sebagai alternative penyajian diskrit (mutually exclusive) (Hill,1988; Wright,1987). Namun hasil yang ditemukan tidak mendukung pernyataan Porter, hasil statistik tidak mendukung hubungan negatif antara strategi kepemimpinan biaya dan strategi diferensiasi, penelitian ini mendukung pandangan dari Hill (1988) yang berpendapat bahwa model porter secara fundamental cacat, sebagai strategi hybrid karna kombinasi antara kedua strategi tersebut mungkin ada dan sesuai di industry tertentu seperti pada penelitian kali ini di industry di Provinsi Banten, sebagai penegasan yang menentang eksklusivitas porter $(1980,1985)$ ditunjukkan pada $\mathrm{H} 3$. Sedangkan hasil statistik dari $\mathrm{H} 1$ dan $\mathrm{H} 2$ menunjukkan adanya hubungan signifikan antara strategi kepemimpinan biaya dan strategi diferensiasi dengan kinerja organisasi. Penelitian ini membawa implikasi penting bagi praktek manajemen, Epstein (2002) menunjukkan bahwa adanya kebutuhan bagi para manajer akan mendorong untuk menyadari hasil kinerja dalam organisasi dan hubungan kausal penting untuk mendorong nilai kinerja. Penelitian ini mencerminkan pentingnya strategi bisnis sebagai pendorong kinerja dan dua penggunaan SPM berpotensi meningkatkan kinerja organisasi. Temuan ini mendukung pentingnya menggunakan pengendalian manajemen baik secara diagnostik maupun interaktif seperti yang dibahas dalam literatur manajemen relatif (Henri, 2006; Simons, 1995; Thoren dan Brown, 2004).

Implikasi Hasil Penelitian. Hasil penelitian ini memberikan informasi, pemikiran dan menambah referensi bagi penelitian selanjutnya, serta member informasi bagi perusahaan industri manufaktur di Provinsi Banten, khususnya bagi manajer dalam mengembangkan 
implementasi penggunaan diagnostik dan interaktif sistem pengendalian manajemen untuk meningkatkan hubungan strategi-kinerja.

Keterbatasan dan Saran penelitian mendatang. Penelitian ini mempunya beberapa keterbatasan atau kelemahan yaitu: (1) Keterbatasan ukuran sampel yang relative kecil yaitu 40 responden dari 95 perusahaan industry manufaktur yang ada di Provinsi Banten. Salah satu penyebab ukuran sampel yang relative kecil tersebut yaitu banyaknya kuesioner yang tidak kembali, karna ukuran sampel yang kecil tersebut mungkin dapat mengurangi kekuatan pengujian statistical. Untuk penelitian yang akan datang diharapkan dapat mengatasi kelemahan dari penelitian ini dengan menggunakan metode kombinasi kualitatif dan kuantitatif

\section{DAFTAR RUJUKAN}

Abernethy, M. A., and Brownell, P. (1999) "The role of budgets in organisations facing strategic change: An exploratory study", Accounting, Organizations and Society, 24 (3): pp. 189-204.

Anthony, R. N. (1965) Planning and Control Systems: A Framework for Analysis, Harvard University, Boston, USA.

Burns, T., and Stalker, G. M. (1961) The Management of Innovation, Tavistock Publications, London, UK.

Campbell-Hunt, C. (2000) "What have we learned about generic competitive strategy? A meta- analysis", Strategic Management Journal, 21 (2): pp. 127-154.

Chenhall, R. H. (2003) "Management control system design within its organizational context: Findings from contingency-based research and directions for the future", Accounting, Organizations and Society, 28 (2-3): pp. 127-168.

DeDreu, C. K. W. (1991) Productive Conflict: The Importance of Conflict Management and Conflict Issue, Sage Publications, London, UK.

Dent, J. F. (1987) Tensions in the Design of Formal Control Systems: A field study in acomputer company, Harvard Business School Press, Boston, USA.

Dess, G. G., and Davis, P. S. (1984)"Porter's generic strategies as determinants of strategic group membership and organizational performance", Academy of Management Journal. 27 (3): pp. 467-488.

Epstein, M. J. (2002) Measuring the Payoffs of Corporate Actions: The Use of Financial and Non-financial Indicators, Elsevier Science, Oxford, UK.

Ghozali, Imam. (2006) Structural Equation Modeling: Metode Alternatif dengan Partial Least Square (PLS). Penerbit Universitas Diponegoro, Semarang.

Govindarajan, V., and Fisher, J. (1990) "Strategy, control systems and resource sharing: Effects on business-unit performance", Academy of Management Journal, 33 (2): pp. 259-285.

Govindarajan, V., and Gupta, A.K. (1985) "Linking control systems to business unit strategy: impact on performance", Accounting, Organizations and Society, 10 (1): pp. 51-66.

Hambrick, D. C. (1983) "Some tests of the effectiveness and functional attributes of Mile's and Snow's strategic types" Academy of Management Journal, 26 (1): pp. 526. 
Hanson, D., Dowling, P. J., Hitt M. A., Ireland R. D., and Hoskisson R. E. (2008) Strategic Management: Competitiveness \& Globalization, 3rd Edition, Cengage Learning Australia Pty Ltd, Victoria, Australia.

Henri, J. F. (2006) "Management control systems and strategy", Accounting, Organizations and Society, 31 (6): pp. 529-558.

Hill, C. W. L. (1988) "Differentiation versus low cost or differentiation and low cost: Contingency framework", Academy of Management Review, 13 (3): pp. 401-412.

Hulland, J. 1999. Use of partial least squares (PLS) in strategic management research: A review of four recent. Strategic Management Journal, 20(2): 195.

Hoque, Z., and James, W. (2000) "Linking balanced scorecard measures to size and market factors: Impact on organizational performance" Journal of Management Accounting Research, 12 (1): pp. 1-17.

Ittner, C. D., and Larcker, D. F. (2001) "Assessing empirical research in managerial accounting: A value-based management perspective", Journal of Accounting and Economics, 32 (1-3): pp. 349-410.

Kaplan, R. S., and Norton, D. P. (2001) The Strategy Focused Organization: How Balanced Scorecard Companies Thrive in the New Business Environment, Harvard Business School Press, Boston, USA.

Kurnianingsih, R. dan N. Indriantoro. (2001) "Pengaruh Sistem Pengukuran Kinerja dan Sistem Penghargaan terhadap Keefektifan Penerapan Teknik Total Quality Management: Studi Empiris pada Perusahaan Manufaktur di Indonesia". Jurnal Riset Akuntansi Indonesia, Vol. 4 (1): 28-43.

Langfield-Smith, K. (1997) "Management control systems and strategy: A critical review", Accounting Organizations and Society, 22 (2): pp. 207-232.

Miller, D. (1992) "The generic strategy trap", The Journal of Business Strategy, 13 (1): pp. 37-41

Murray, A. I. (1988) “A contingency view of Porter's "generic strategies", Academy of Management Review, 13 (3): pp. 390-400.

Nicotera, A. M. (1995) Conflict and Organizations, New York Press: Albany, NY, USA.

Norreklit, H. (2000) "The balance on the balanced scorecard - A critical analysis of some of its assumptions", Management Accounting Research, 11 (1): pp. 65-88.

Otley, D. (1994) "Management control in contemporary organizations: Towards a wider framework", Management Accounting Research, 5 (3-4): pp. 289-299.

Porter, M. E. (1980) Competitive Strategy: Techniques for Analysing Industries andCompetitors, The Free Press, New York, NY, USA.

Porter, M. E. (1985) Competitive Advantage, The Free Press, New York, NY, USA.

Richard, P.J., Devinney, T.M., Yip, G.S., and Johnson, G. (2009) "Measurin Organizational Performance: Towards Methodological Best Practice", Journal of Management, 43 (2), pp. 109-116.

Robinson, R. P., and Pearce, J. A. (1988) "Planned patterns of strategic behaviour and their relationship to business-unit performance" Strategic Management Journal, 9 (1): pp. 43-60.

Rubach, M.J. McGee, J. E. (2004) "Responding to increased environmental hostility: A study of the competitive behavior or small retailers", Journal of Applied Business Research, 13 (1): pp. 83-94. 
Sands, J. (2006) Strategic Priorities, Management Control Systems, and Managerial Performance: An Empirical study (Unpublished $\mathrm{PhD}$ thesis), Griffith University: Australia.

Simons, R. (1990) "The role of management control systems in creating competitive advantage: New perspectives", Accounting Organizations and Society, 15 (6): pp. 127-143.

Simons, R. (1995) Levers of Control: How Managers Use Innovative Control Systems to Drive Strategic Renewal, Harvard Business School Press, Boston. USA.

Thorén, K., \& Brown T. E. (2004) "The Entrepreneurial Firm: Resources, Capabilities, and Perceptions", Journal of Management Studies (special issue), Ohio State, USA.

Tucker, B., Thorne, H., and Gurd, B. (2009) "Management control and strategy - What's been happening", Journal of Accounting Literature, 28 (2): pp. 123-163.

Vandenbosch, B. (1999) "An empirical analysis of the association between the use of executive support systems and perceived organizational competitiveness" Accounting, Organizations and Society, 24 (1): pp: 77-92.

Wickramasinghe, D. and Hopper, T. (2005) "A cultural political economy of management accounting controls: A case study of a textile mill in a traditional Sinhalese village", Critical Perspectives on Accounting, 16 (4): pp: 473-503.

Wright, P. (1987) “A refinement of Porter's Strategies”, Strategic Management Journal, 8 (1): pp. 93-101. 